\title{
Barát vagy ellenség? Negatív online fogyasztói értékelések szerepe az Airbnb oldalon
}

\author{
Szerző́k: Féki Zsuzsanna ${ }^{1}$ - Markos-Kujbus Éva²
}

Az e-WOM (eletronic word-of-mouth, online szájreklám) értelmezhetô valamely szolgáltatásról alkotott pozitív vagy negatív állításként. A negatív töltetú e-WOM háttérbe szorul a kutatásokban, igy ennek befolyásoló hatása került kutatásunk középpontjába.

Az online szállásfoglalásnál a fogyasztók nem tudnak előzetesen meggyőződni a minôségröl, igy kénytelenek társaik véleményére hagyatkozni, tehát az e-WOMnak kiemelt szerep jut. Az egyik legnépszerúbb szállásfoglaló oldal, az Airbnb, müködésének alapja a közösség és a tagok által alkotott fogyasztói értékelések, amelyek segítenek másoknak az észlelt kockázat csökkentésében és a döntés meghozatalában. A fentiek alapján kutatásunk arra fókuszált, hogyan jelenik meg a negatív e-WOM a fogyasztók szálláskeresési folyamatában.

Kutatásunk eredménye alapján elmondható, hogy elsôsorban azon hozzászólások a hasznosak, melyek extra információt szolgáltatnak, valamint hogy a szélsôségesen negatív e-WOM háttérbe szorul az objektivitás hiánya miatt. Láthatóvá vált továbbá, hogy bár a negatív e-WOM képes elrettentô hatást gyakorolni, releváns tartalom esetén azonban felkészít a szállás hiányosságaira.

Kulcsszavak: negatív e-WOM, Airbnb, fogyasztói döntéshozatal, online szálláskeresés, sharing economy.

\section{Bevezetés}

$\mathrm{Az}$ e-WOM (electronic word-of-mouth, online szájreklám, továbbiakban e-WOM) a társas befolyásolás és kommunikáció egy olyan formájának és eszközének tekinthető, amely alapvetóen a fogyasztók között zajlik. Ugyanakkor a szervezetek számára is elérhetô, és lehetőségük van a fogyasztóval való közvetlen kommunikációra. Az e-WOM tartalma termékről, szolgáltatásról, márkáról, vállalatról vagy személyról szóló pozitív vagy negatív állítás lehet (MARKOS-KUJBUS 2016). A negatív e-WOM fogyasztói döntésre gyakorolt hatását tekintve nincs egyetértés a szakirodalomban (például v.ö. EAST et al. 2007, CHEN-LURIE 2013), így kutatásunk erre az irányra fókuszál. Elmondható továbbá, hogy a fogyasztói véleményeknek kiemelt szerepe van az online szálláskeresés folyamatában, hiszen gyakran ez az egyetlen forrás a döntéshozatalhoz (MARKOS-KUJBUS 2016). A fentiek alapján kutatási kérdésünk: hogyan jelenik meg a negatív

\footnotetext{
alumni hallgató, Budapesti Corvinus Egyetem, feki.suzy@gmail.com

${ }^{2}$ adjunktus, Budapesti Corvinus Egyetem, eva.kujbus@uni-corvinus.hu
}

e-WOM a fogyasztók szálláskeresési folyamatában? Ennek vizsgálatához az Airbnb oldal szolgált alapul, valamint fókuszcsoportos vizsgálatot végeztünk olyan magyar fiatal fogyasztók bevonásával, akik beszélik az angol nyelvet és már legalább egyszer foglaltak az oldalon, tehát ismerik a múködését.

\section{Szakirodalmi áttekintés}

\subsection{A NEGATÍV E-WOM}

Amíg a pozitív e-WOM a fogyasztó hajlandósága a termék vagy szolgáltatás ajánlására más fogyasztók számára (GRUEN et al. 2006), addig a negatív e-WOM egyfajta közvetett véleménynyilvánítási stratégia alkalmazása (CSORDÁS 2015) egy kellemetlen vásárlási élménnyel kapcsolatban, amivel a véleményezố eltántoríthatja a felhasználókat a használattól vagy igénybevételtől (CHEUNG-THADANI 2012).

A negatív e-WOM folyamatának (1. ábra) első lépcsőfoka a fogyasztói elégedetlenség kialakulása. „A vevői elégedettség azt fejezi ki, hogy a szolgáltatás mennyiben felel meg a vevô elvárásainak" (KENESEI-KOLOS 2007:128). Ha a fogyasztó elvár egy bizonyos 
végeredményt, és ahhoz képest a tapasztalatai rosszabbak, akkor elégedetlenné válik. A fogyasztó elvárásai származhatnak vállalati kommunikációból, saját múltbeli tapasztalataiból, felmerült igényeiből, értékeiból vagy más fogyasztóktól, azaz (e-)WOM kommunikációból (BAUER et al. 2007).

1. ábra

\section{A negatív e-WOM kialakulásának folyamata}

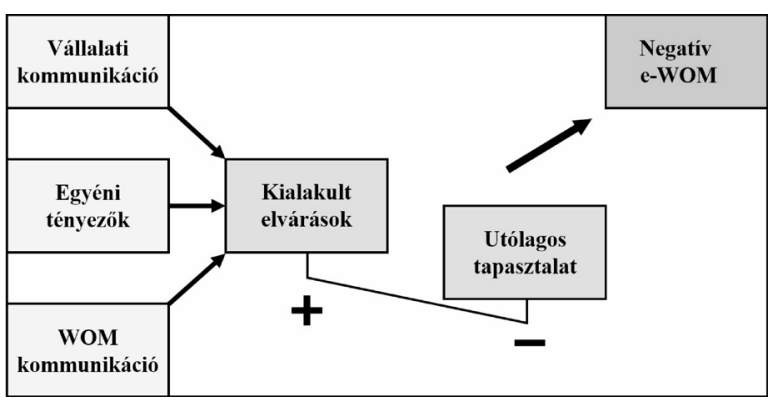

Forrás: saját szerkesztés

Az online környezetben a fogyasztói elégedettség jelentősége felértékelódik, hiszen az eladó és a vásárló nem találkozik egymással, a fizetés gyakran a megrendeléssel együtt történik. Ha a vásárló csalódik a termékben, nem fogja azt újból megrendelni és társait is figyelmezteti e-WOM kommunikáció révén (YEN-TANG 2015).

A negatív e-WOM vonatkozásában elmondható, hogy azok a fogyasztók, akik az adott termék, szolgáltatás minôségével elégedetlenek, nagyobb valószínúséggel vesznek részt a negatív e-WOM létrehozásában, mint azok, akik az árral elégedetlenek (WANGENHEIM 2005). Továbbá minél elégedetlenebb (vagy épp elégedettebb) a fogyasztó, annál több e-WOMot fog létrehozni (LITVIN et al. 2008). Bár a legtöbb fogyasztó elégedettségi szintje jellemzóen a mérsékelt tartományban mozog (SCHNEIDER-BOWEN 1999), ami nem von maga után nagyobb mennyiségú e-WOMot, a szélsóségesen elégedett és elégedetlen állapotokban sokkal intenzívebb az e-WOM (CSORDÁS 2015).

Az elégedetlenség mellett számos további tényezó is hat az e-WOM létrehozására (EAST et al. 2007), melyek közül kiemelkedik a fogyasztó motivációja. Ennek egyik esete, amikor a fogyasztó a csalódottságból fakadó frusztrációját akarja csökkenteni. Egy kellemetlen utazási élmény például negatív érzést kelthet, melynek hatására a vásárló haragot érez, aminek csökkentésére, továbbá a pszichológiai egyensúly visszaállítására, értékelést oszt meg az online platformokon. Ugyanígy moti- váció lehet a szándék, amikor a fogyasztó másokat szeretne megakadályozni abban, hogy az általa már átélt problémákat elszenvedjék. Egy másik eset, amikor a fogyasztó arra törekszik, hogy a vállalatot mozdítsa előre a probléma feltárásában és javításában (BRONNER-DE HOOG 2011, YENTANG 2015).

A negatív e-WOM elsődleges szerepe és hatása, hogy információforrásként jelenik meg, hiszen általános jellemzóje, hogy leíróbb, feltáróbb és kirívóbb (nem szokványos) részleteket tartalmaz (LEE et al. 2008). Ezenfelül a negatív e-WOM révén a fogyasztó akár új, exkluzív információkhoz is hozzáfér, így a negatív e-WOM az információs aszimmetriát, a döntési kockázatokat és a döntési disszonanciát is képes csökkenteni (VERHAGEN et al. 2013).

A negatív vélemények másik fontos szerepe a termék, márka, vállalat iránti attitúd változásában fedezhető fel. LEE és CRANAGE (2014) kutatása alapján várhatóan nagyobb mértékú lesz az attitúdváltozás a negatív e-WOMmal való találkozás következtében. Vagyis a negatív e-WOM közvetlenül a vásárlási döntésre képes hatni, hiszen akár el is tántoríthatja a fogyasztót a vásárlástól.

RICCI és WIETSMA (2006) eredményei alapján ugyanakkor a negatív vélemények a vásárlási döntés megerősítéséhez is hozzájárulhatnak. PARK és LEE (2008) megállapította, hogy a negatív e-WOM nagy hatással van a fogyasztók vásárlási szándékára: a befolyásolt fogyasztók esetében alacsonyabb a vásárlási szándék, mint azoknál, akik nem adnak a negatív véleményekre. Továbbá, ha a negatív információk egy termékkel vagy szolgáltatással kapcsolatban összecsengenek, akkor a potenciális fogyasztók nagyobb magatartásváltozást mutatnak negatív irányba (LEE-CRANAGE 2014).

A negatív e-WOM kettôs hatását mutatja, hogy a fogyasztói döntéshozatalt tekintve HU és szerzôtársai (2006) megállapították, hogy az e-WOM nem feltétlenül tükrözi a tényleges termék- vagy szolgáltatásminőséget, ami torzíthatja a fogyasztók döntését. Ennek az lehet az oka, hogy a fogyasztók nagyobb valószínúséggel osztják meg tapasztalataikat, ha azok szélsőségesek, például szélsőségesen negatívak, mint amikor egy kellemes, de viszonylag semleges élményben volt részük (ÖZ 2015).

Azonban bizonyos elemek jelenléte mellett a negatív e-WOM kevésbé hatásos vagy éppen hatástalan. Például, ha a negatív e-WOMban az információk ellentmondanak egymásnak vagy az egyes véleményekben leírtak inkonzisztensek. Ilyenkor a fogyasztó összezavarodik, és kevésbé fogja hitelesnek találni az információt, így valószínúleg figyelmen kívül hagyja a negatív e-WOMot (CHANGWU 2014). Továbbá, ha a vélemény olvasójának 
Lektorált tanulmányok

erôs az érzelmi bevonódása és magas szintú az elköteleződése, szintén hatástalan lesz a negatív e-WOM, hiszen az olvasó érzéketlenné válik vele szemben (LACZNIAK et al. 2001).

A vállalatok szempontjából a negatív e-WOM legfontosabb hatása a termék- és márkaértékre, -értékelésre vonatkozik. Amikor a fogyasztó a negatív e-WOMban megjelenő tényezót a márkának tulajdonítja, akkor számára a márka értéke csökkenni fog. A vásárlási szándék csökkenése az eladások csökkenéséhez is vezethet (CHEN-LURIE 2013). A negatív e-WOM azonban nemcsak negatív hatással lehet a vállalat szempontjából, mivel megfeleló felhasználás esetén egyrészt visszajelzést ad, ami lehetóséget teremt a problémák feltárására, valamint közvetlen kommunikációs és befolyásolási lehetőséget nyújt a fogyasztói panaszok kezelése során (DE BRUYN-LILIEN 2008).

\subsection{A SHARING ECONOMY}

A sharing economy ${ }^{3}$ piaci közvetítésú tranzakciókat foglal magában, amelyek ideiglenesen korlátozott hozzáférést biztosítanak a fogyasztóknak a javakhoz, szolgáltatásokhoz úgynevezett hozzáférési díj ellenében (SCHAEFERS et al. 2016). RIFKIN (2014) a sharing economyt egy gazdasági modellként értelmezte, ahol a digitális platformok segítségével a tagok állandó kapcsolatban állnak egymással, és a fogyasztói igények felmerülésükkor azonnal ki vannak elégítve. CODAGNONE és munkatársai (2016) szerint a sharing economy nem idegenek, hanem a közösség tagjai közötti cserék megkönynyítésére szolgál, ami bár támaszkodik a technológiára, előnyben részesítheti az offline tevékenységeket.

\section{A sharing economy platformok típusai}

2. ábra

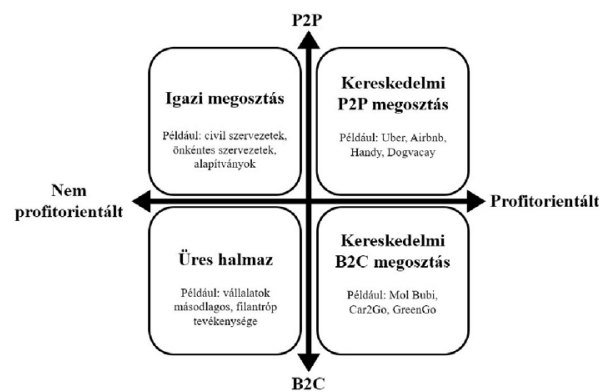

Forrás: saját szerkesztés CODAGNONE és MARTENS (2016) alapján

\footnotetext{
3 A sharing economy elnevezésében nincs egyetértés a kifejezés pontosságát illetően, és születtek új megnevezések is, mint például collaborative consumption (közösségi fogyasztás), peer-to-peer platforms (egyenrangú felek közti platform) (SLEE 2015). Éppen ezen okok miatt a továbbiakban a sharing economy kifejezést használjuk.
}

CODAGNONE és MARTENS (2016) a sharing economy platformokat két dimenzió mentén jellemezte (2. ábra). Az egyik dimenzió a profitszerzés alapján csoportosít profitorientált és nem profitorientált tevékenységeket. Profitorientált esetben az a cél, hogy minél több tranzakció történjen, amelyek után jutalékot kap a platform. A nonprofit platformok esetében a megosztó elemek dominálnak (DUDÁS-BOROS 2019). A másik dimenzió a tranzakcióban szereplő felek szerint csoportosít, ezáltal különít el B2C (business-to-customer, azaz vállalat és fogyasztó közötti) és P2P (peer-to-peer, azaz fogyasztók közötti) platformokat. Habár magát a P2P platformot vállalatok tulajdonolják és múködtetik, a tranzakció elsődleges szolgáltatóinak (akik az eszközt birtokolják) a magánszemélyek tekinthetőek.

A 2. ábrán bemutatott négy kategória a következô. A bal felsô negyed azokat a platformokat jelöli, ahol a megosztás eredeti motívumait fedezhetjük fel, a felek között csere megy végbe, a fő motiváció a jószándék, és nem cél a profitszerzés. A bal alsó negyedbe tartoznak azok a vállalkozások, amelyek nonprofit módon üzemelnek, azonban a vállalkozások definíciója szerint nyereségre törekednek, ilyenek például a közösségi alkotómúhelyek. Az jobb felsố negyedbe olyan platformok sorolhatók, amelyek megkönnyítik a személyek közötti tranzakciókat. Olyan ismert cégek tartoznak ide, mint az Uber, Airbnb, Handy, Dogvacay (CODAGNONEMARTENS 2016). A P2P profitorientált modellek esetében a három alkotóelem a platform, a vállalkozó és a fogyasztó. A platformok biztosítják a csatornát az áruk és szolgáltatások cseréjéhez. A vállalkozók a magánszemélyek, akik árukat vagy szolgáltatást kínálnak ezen a piacon anyagi juttatásért cserébe. A fogyasztók pedig azok az egyének, akik a szükségleteiket vásárlással, bérléssel vagy csere által elégítik ki (SUNDARARAJAN 2014). A jobb alsó negyedben a sharing economy összekapcsolódik a hagyományos B2C online tevékenységekkel (CODAGNONE-MARTENS 2016). A B2C üzleti modell lényege, hogy a kínálati oldal és a közvetító platform egyesül, így a cég saját online felületén kínál erőforrásokat a fogyasztóknak. A vállalkozások ugyanis felismerték, hogy a sharing economy jelenségben számos kedvezó lehetôség rejlik számukra, és ennek az új forrásnak a segítségével növelhetik bevételeiket. Ilyen vállalati példa a hazánkban népszerú MOL Bubi közösségi kerékpárbérlő szolgáltatás (PWC 2015a).

Összességében elmondható, hogy a sharing economy fogalmát és a hozzá kapcsolódó platformok kategorizálását az határozza meg, hogy mi jellemzi a felhasználók közötti interakciókat (P2P vs. B2P), hogy milyen fókusz jellemzi a platformo- 
kat (megosztás vs. árucsere), valamint hogy milyen a platformok irányultsága (forprofit vs. nonprofit) (DUDÁS-BOROS 2019).

A sharing economy fô területei a közlekedés, a fogyasztói javak, az emberi erőforrások, a lakás-, illetve pénzügyi szektor és nem utolsó sorban a vendéglátás és turisztika (PWC 2015). A turizmusban a P2P (személyek közötti) platformok óriási növekedést mutattak, ami a szálláskiadáson túl igaz a vendéglátásra, a közlekedésre és a városnéző túrákra is (CHENG 2016). A személyek közötti interakciók elősegítése a sharing economy jelenség alaptényezője. A tranzakcióban szereplő, egymást nem ismeró felek közötti bizalom kulcsfontosságú, a múködés alapelemének számít (ERT et al. 2016). A P2P piacon az egyik legjellemzőbb módszer a bizalom elôsegítésére a fogyasztói véleményezésen alapuló értékelô rendszer létrehozása, ahol a felek online visszajelzést adnak egymásról, illetve a szolgáltatás minőségéről, milyenségéről (MARTIN-FUENTES et al. 2018).

A sharing economy múködéséhez elengedhetetlenek az online fogyasztói vélemények, a személyek közötti kommunikáció és a bizalmi rendszer (TUSSYADIAH-ZACH 2017). Egy közösségi gazdaságon belül kulcsfontosságú a bizalom, tekintve, hogy a garanciát jellemzően a fogyasztók értékelései jelentik, melyek hatással vannak a vásárlási döntés meghozatalára is (BOROS-DUDÁS 2017). Ezt jól szemlélteti, hogy az információs aszimmetria csökkentése az e-WOM közvetító szerepén keresztül történik, amikor harmadik fél által múködtetett oldalak (például Airbnb) értékelési mechanizmusokat hoznak létre (JANCSIK et al. 2018)

A legtöbb sharing economy vállalat - teret engedve az e-WOMnak - kiépítette a fogyasztói értékelő rendszerét (reputation system), ahol a fogyasztók kedvük szerint kereshetnek és oszthatnak meg információkat tapasztalataikról, a szolgáltatás élményéról, így befolyásolva mások vásárlási szándékát és döntéshozatalát (RESNICKZECKHAUSER 2002). Egy utazás tervezésénél például a fogyasztók elószeretettel keresgélnek az online ajánlások között, és próbálnak minél szélesebb körú információhoz jutni, mielótt bármit lefoglalnának (KIM et al. 2011).

\section{Módszertan}

Kutatásunk középpontjába a sharing economy egy tipikus felülete, az Airbnb került. A felület kiválasztását indokolja, hogy napjaink egyik legnépszerúbb platformja az utazók között, hiszen 2019-ben több mint 150 millió felhasználója volt, akik több mint 191 országból származó, 6 millió szálláshely közül választhattak (AIRBNB 2019). Ahogy a legtöbb sharing economy vállalatnál, az Airbnbnél is a fogyasztói értékelő rendszer a múködés alapköve. A vendégek visszajelzései négy részből állnak: a nyilvános fogyasztói értékelésekből; a szállásadónak adott üzenetekből; az egytől ötig terjedô csillagértékelésból; illetve a szállás tisztaságának, a leírás pontosságának, az ár-érték aránynak, a szállásadóval történő kommunikációnak, a zökkenőmentes érkezésnek és az elhelyezkedésnek az osztályozásából. Hasonlóképpen a szállásadó is értékelheti a vendégeket, megjegyzést írhat róluk, és osztályozhatja ooket kommunikáció, tisztaság és udvariasság szerint. Ez alapján a szállásadó és a vendég oldalán is elérhetóek a róluk írt nyilvános kommentek, illetve egy a korábbi összes csillagminósítésből átlagolt pontszám.

A fentiek alapján megfogalmazott kutatási kérdésünk: Hogyan jelenik meg a negatív e-WOM a fogyasztók szálláskeresési folyamatában?

A kutatási kérdés megválaszolásához fókuszcsoportos interjúkat készítettünk. A kvalitatív kutatási szemléletmód mellett szól, hogy jelen kutatás fókusza a problémák megértésén és a mélyben rejló okok, magyarázatok megismerésén van (GYULAVÁRI et al. 2015). A kvalitatív kutatás egyik típusa a fókuszcsoportos interjú, amely nevéból kifolyólag csoportbeszélgetést takar, ahol a kutató arra buzdítja a csoport tagjait, hogy interakcióba lépjenek egymással (GYULAVÁRI et al. 2015). A fókuszcsoportos vizsgálat jogosultságát támasztja alá, hogy a negatív fogyasztói vélemények értelmezését és szerepét számos tényező befolyásolja, amelyek közül kiemelkedik a csoporttagokkal való interakció. A kutatás fó témája, a szálláskeresés, nem számít érzékeny témának, nincs társadalmi nyomás a résztvevókön, így zavartalanul léphetnek interakcióba. Kutatási módszertanunkat indokolja továbbá, hogy a vizsgált felületet (AirBnb) tekintve elsősorban kvantitatív módszereket alkalmaztak a kutatók az elmúlt években (például MAO-LYU 2017, LIANG et al. 2018, BRIDGES-VÁSQUEZ 2018). Célunk továbbá a téma- a negatív vélemények szerepe - relevanciájának alátámasztása és pontosítása a kutatási folyamat későbbi fázisai számára.

A fókuszcsoportos interjúk esetében szúrőfeltételeket alkalmaztunk az interjúalanyok kiválasztása során. Az volt a célunk, hogy olyan alanyokat találjunk, akik legalább egyszer foglaltak már szállást az Airbnb oldalon keresztül, hisz így ismerik a rendszer alapvetô múködését. További feltételként jelenítettük meg az angol nyelvtudást, amelyet a rendszer használata is feltételez. Ezen jellemzők 
Lektorált tanulmányok

mentén alanyainkat két csoportra osztottuk az online szállásfoglalás gyakorisága alapján: tapasztaltak és újoncok (1. táblázat). A szétválasztást indokolja, hogy feltételezésünk szerint az, aki már legalább tízszer foglalt szállást az interneten, tapasztalttá válik, pontosan tudja, milyen igényei vannak, továbbá az online fogyasztói vélemények olvasásában és értékelésében is rutinos. Ezek alapján elózetes elvárásunk, hogy az a fogyasztó, aki kevesebbszer használt online szállásfoglaló oldalakat, vélhetően más preferenciaszettel rendelkezik, eltérô lehet a véleményolvasási ideje és módja, illetve máshogy hathatnak rá a negatív hozzászólások.

1. táblázat A fókuszcsoportok tagjainak legfóbb jellemzői

\begin{tabular}{|c|c|c|}
\hline Szempontok & Tapasztaltak & Újoncok \\
\hline $\begin{array}{l}\text { Airbnb használati } \\
\text { gyakorisága }\end{array}$ & $\begin{array}{l}\text { tíznél több } \\
\text { alkalommal } \\
\text { foglaltak online } \\
\text { szállást }\end{array}$ & $\begin{array}{l}\text { tíznél kevesebb } \\
\text { alkalommal } \\
\text { foglaltak online } \\
\text { szállást }\end{array}$ \\
\hline Életkor & 21-34 év között & 21-27 év között \\
\hline Végzettség & egyetemi & egyetemi \\
\hline Utazási szokások & $\begin{array}{l}\text { hosszabb } \\
\text { utazások, } \\
\text { gyakoribb utazók, } \\
\text { saját maguknak } \\
\text { foglalják a } \\
\text { szállást }\end{array}$ & $\begin{array}{l}\text { rövidebb utazások, } \\
\text { elsôsorban } \\
\text { szórakozás } \\
\text { céljából utaznak, } \\
\text { jellemzóen mások } \\
\text { foglalják számukra } \\
\text { a szállást } \\
\end{array}$ \\
\hline Létszám & 6 fö (4 nô, 2 férfi) & 6 fő (3 nô, 3 férfi) \\
\hline Csoportok tagjai & $\begin{array}{l}\text { T1, T2, T3, T4, } \\
\text { T5, T6, }\end{array}$ & $\begin{array}{l}\text { U1, U2, U3, U4, } \\
\text { U5, U6, }\end{array}$ \\
\hline
\end{tabular}

Forrás: saját szerkesztés

A két fókuszcsoportos interjúra 2018. október 10én és 13-án került sor egy egyetemi tanteremben, nyugodt körülmények között. Az interjúk idótartamukat tekintve 75 és 90 percesek voltak, ahol az interjúalanyokon kívül egy kutató volt jelen, az elhangzottakról pedig - az interjúalanyok engedélyével - hangfelvétel készült. A feldolgozás során az elemzést két független kódoló végezte el.

Az interjúk során az e-WOMmal, ezen belül is hangsúlyosan a negatív e-WOMmal, valamint az Airbnbvel kapcsolatos fogyasztói tapasztalatok és vélemények kerültek elótérbe. Végül egy szimuláció során döntési helyzetbe helyeztük az interjúalanyokat, ahol valós vélemények alapján kellett választaniuk. A döntési folyamat során az alanyok pozitív, negatív fogyasztói értékelésekkel kapcsola- tos reakcióját, hozzáállását, magatartását figyeltük meg.

\section{Eredmények A fókuszcsoportok jellemzése}

Elófeltevéseink beigazolódtak, ugyanis a tapasztaltak csoportjában az összes interjúalany sokkal magabiztosabban és rutinosabban vette szemügyre a fogyasztói véleményeket, mint az újoncok, akiknek még kevés alkalma volt online szállást foglalni, így ók mások döntésére hagyatkoztak a leggyakrabban.

A szállásokról szóló fogyasztói vélemények szempontjából az újoncok fóleg a vélemények tartalmára és a negatív, pozitív tartalmak arányára fókuszáltak. A tapasztaltakat ezek mellett több tényezó is érdekelte: a vélemény írójának tartózkodási ideje, melynél a hozzájuk hasonló tartózkodásokat részesítették elónyben, valamint a vélemény kelte, mely alapján akár elavult információkat is tartalmazhatott.

A két csoport között eltérô igény alakult ki a vélemények formai követelménye iránt. A fogyasztók igényei különbözőek az érvelésekkel és a vélemény hosszúságával kapcsolatban: a tapasztaltak a szépen megírt, megfelelóen szerkesztett hozzászólásoknak nagyobb jelentőséget tulajdonítottak: „Ha helytelenül írnak, vagy összevisszának érzem a szöveget, akkor nem valószínú, hogy hatással lesz rám, mert nem bízom benne... Jobban szeretem a hosszabb kommenteket, amik jobban a részletekbe mennek." (T2)

Ezzel szemben a másik csoport egyértelmúen fókuszáltan keres, a tömör kommenteket preferálja: „Nem feltétlenül kell nekem regény, nem szívesen olvasok litániákat... Megtudtam, amit akartam, inkább olvasok egy ilyet, mint egy hosszút." (U6)

A negatív e-WOM kérdéskörében a tapasztaltak határozottan különbséget tettek a negatív értékelések között, illetve sokkal bizakodóbbak voltak: „Szerintem nagyon sok olyan komment van, amik lehúzzák (a helyet), de a hely nem is ígérte azt. Ugyanakkor, ha valamit ígért (a hely), akkor jogos...tartsa is be." (T5)

Az újoncok az észlelt kockázatot felértékelték, emiatt a negatív kommentek egyértelmúen negatív hatással voltak a döntéshozatalukra, valamint kivétel nélkül minél egyszerúbben és gyorsabban próbálták megszerezni a szükséges információkat: „Ha valami kell (értsd: valamit fontosnak tartasz) ezek közül, amit ô negatívan értékelt, akkor köszönöd a véleményt és mész tovább egy másik szállásra." (U2)

$\mathrm{Az}$ Airbnbn megjelenő véleményekkel kapcsolatban általánosan jellemezte az interjúalanyokat, 
hogy átpörgetik a szállás képeit és a szállásadó által írt jellemzést, de a legnagyobb hangsúlyt a fogyasztói értékelések kapják, amely alátámasztja a kutatási témánk relevanciáját.

A nagy mennyiségú véleményáradatot nem kifogásolták egyik csoport tagjai sem, azonban fontosnak tartották, hogy az oldal biztosítsa a kényelmes navigációt, hogy könnyedén lehessen keresni, szúrni az információk között. A számszerúsített (csillaggal jelölt) értékeléseket erre alkalmasnak tartották. Ugy gondolták, hogy az értékelés ezen formája bár nem ad a döntésükhöz elegendő információt, kiindulásnak tökéletes a szállások szelektálásában. Az ellentétes, megtévesztő hozzászólások nehézséget jelentettek az interjúalanyoknak: „Nagyon összezavarva éreztem magam. Megtévesztók a véleménykülönbségek, de több rosszat olvastunk, mint jót, így hátrébb raktam a sorrendben." (U5)

Elmondható, hogy szükség van olyan funkciókra, amik lehetôvé teszik az információk szúrését és csoportosítását. Ezek hiányában a vélemények nagy száma és rendezetlensége megnehezíti a döntést, és hosszabbá teszi a döntési idôt.

A csoportok egybehangzó vélekedését jól mutatja a következő vélemény, amely szerint akkor „Jó egy komment, ha olyan dolgokra is kitér, amelyek nincsenek benne a szállás leírásában, mert akkor ez egy plusz információ lehet a felhasználó számára." (T3) Erre példaként merült fel a tisztaság fogalma, amely szubjektív tényezóként jelent meg. A tisztaságról alkotott negatív vélemények az interjúalanyokat több esetben eltántorították a szállás választásától. A tisztaság fogalmának értelmezésében és fontosságában egyik csoportban sem értettek egyet a tagok, ami visszavezethetó arra a tényre, hogy a fogalom mindenki számára mást jelent, és mások az elvárásai.

Az interjúalanyok számára a vélemény hatását befolyásolta a véleményíró személye. Fontosnak tartották tudni, hogy a kommenteló milyen kultúrából származik. Ezt azzal magyarázták, hogy egy másik kultúrában a tisztaság vagy egyéb szubjektív faktorok megítélése különböző. Ha ezt nem tudták eldönteni, kevesebb bizalmat szavaztak a véleményezőnek, és az általa írt értékelést nem, vagy nem olyan súllyal vették figyelembe. Ezek mellett láthatóvá vált, hogy a tapasztaltak csoportjában minden interjúalany erőfeszítéseket tett annak érdekében, hogy beazonosítsa a hozzászóló személyét: „Az Airbnb-n látszik, hogy ki kommentel, milyen osztályozása van, mennyit utazik, mi a neve, ezért jobban beazonosítható a komment." (T6) Emellett, ha az alanyok nem tudták kideríteni a vélemény forrását, akkor hiteltelennek tartották a leírtakat is. Mindez egybehangzik azzal a megállapítással, hogy ha a vevő hitelesnek ítéli a vélemény forrását, akkor valószínúbb, hogy hasznosnak fogja tartani az általa közzétetteket, és nagyobb lesz a hajlandósága lefoglalni az adott szállást (GHEORGHE 2018).

Az interjúk során az alanyok többször említették a negatív véleményeket, mint a döntésüket befolyásoló hasznos és fontos tényezóket, de végsó választásukat nem kizárólag azokra alapozták: "Szerintem fontos a pozitív komment is, mert az alapján keresed a szállást, hogy a kommentek milyen arányban vannak." (T2)

Ennek ellenére nem lehet kijelenteni, hogy kizárólag a pozitívumok számítottak, mert bizonyos esetekben, ha számukra releváns negatívummal találkoztak, az interjúalanyok megváltoztatták a döntésüket. Ugyanakkor megjegyzendô, hogy eltérés jelent meg mindkét csoporton belül, ugyanis néhány résztvevô szerint a nagyon pozitív vélemények elsősorban befolyásolási céllal jönnek létre, így ezeket érdemesebb figyelmen kívül hagyni. Az interjúalanyok többsége szerint azonban a manipulatív vélemények hamar kitúnnek, így érdemes bízni a véleményekben.

Sokan a saját véleményüket is arányokkal támasztották alá, ami megmutatta a negatívumok érzékelt szerepét. Több résztvevőt a kevés negatív információ riasztotta el, így inkább másik szállás után néztek: „Ha a 10 kommentból 2-3 ilyet mond, akkor annak van valóság alapja, és akkor az ilyet alapból skippelni kell (értsd: ezt a szállást nem szabad választani).” (T5) „Ha 100-ból van 3 ilyen, az nem zavar, de ha 10-ből, akkor igen... tehát az is számít, hogy hány kommentből van". (U3)

A negatív vagy pozitív információ hatása a hozzászólások tartalmától is függött. Például voltak, akiknek nem volt releváns a Wi-Fi erősségének kérdése, mivel ôk rendelkeztek mobilinternettel. Emiatt azokat a fogyasztói véleményeket, amelyekben e tényezôt sérelmezték, nem érezték negatívnak. Felmerült az a vélemény, hogy egyes fogyasztók szeretik, ha feltúnik egy-két negatív komment a pozitívak között, ugyanis számukra ezek információval szolgálnak, amivel jobban fel tudnak készülni a szállás hiányosságaira: „Jó tudni, ha nincs tusfürdő, mert akkor beteszem a bőröndbe: Ilyen egyszerú!!" (T1)

A tapasztaltak csoportjában merült fel, hogy meggyőzően hatott, ha a hozzászólás pozitív és negatív tényezóket is tartalmazott, mondván: „Olyan nincs, hogy minden tökéletes." (T6)

Többen is említették, hogy szeretnek negatív értékeléseket olvasni, hogy meggyőzzék magukat a választás kapcsán: „Ha nagyon sok rövid hozzászólást olvasok, utána szeretek egy hosszút is megnézni, csak hogy tisztán lássak, és biztos le- 
Lektorált tanulmányok

gyek benne, hogy ugyanazt mondja-e végül, mint a többi és lehúzza-e a helyet, vagy nem." (T5)

A megfigyeltek egybehangzanak RICCI és WIETSMA (2006) kutatásával, mely szerint a negatív vélemények segítik a vásárlási döntés megerōsítését. A negatív hozzászólások elolvasása után a fókuszcsoportok résztvevőinek vásárlási magabiztossága megszilárdult, biztossá váltak a döntésükben.

Általános vélekedés volt, hogy ha a véleményezők többsége számára elfogadhatatlan a hely, vagy bizonyos negatívumok újra és újra felmerültek, akkor azt a fókuszcsoportok tagjai valósnak érzékelték: „Egyszer lehet piszkos, de ha mindenki panaszkodik, akkor nem fogom lefoglalni." (T3) „Ha a szállás alatt az első 3 komment, amit elolvasok negatív, nem foglalkozom vele tovább." (U1)

A negatív fogyasztói véleményeket tehát meghatározónak ítélték a résztvevók, és egyéb faktorokkal - például ár - összevetve el tudták dönteni, hogy megéri-e nekik az adott szállás: „Tényleg, ha valami olcsó, ne is várjuk el, hogy olyan magas szintú legyen." (U3)

A feltártak párhuzamban vannak LEE és CRANAGE (2014) megállapításával, azaz amenynyiben a negatívumok összecsengenek, a fogyasztó magatartása negatív irányba fog változni.

A két fókuszcsoport közti különbség abban is megmutatkozott, hogy az újoncok próbálták minél egyszerúbben és gyorsabban megszerezni a szükséges információkat, így ők a kulcsszavakra fókuszáltak: „Dissappointed, never, inconvenience... ez már nagyon meggyózó! El se kell olvasnom, amikor meglátom, hogy mindegyik negatív szóval kezdődik..." (U2)

Sokan keresték az objektív vagy legalábbis számukra objektívnek túnó véleményeket. Például a szélsőségesen negatív értékeléseket nem tartották életszerúnek a tagok, így nem is vették figyelembe a választásuk során: „,Számomra nem hitelesek! ... Szerintem ezeknél az oldalaknál, ha tudod bizonyítani, hogy tényleg problémád volt, akkor kompenzálnak, és a szállásadó csak jobban jár." (T5)

Az extrém hozzászólásokat elvetették a jelen lévő́k, mert nem tûntek objektívnek. Sót, hiteltelennek érezték, hogy az író csak negatívumokat sorakoztat fel.

\section{5. Összefoglalás}

Online szállásfoglalás esetén a fogyasztók észlelt kockázata magas, így nagy hangsúly helyeződik az e-WOM kommunikációra (KENESEI-KOLOS 2007). Gyakori az elégedetlen fogyasztó, és az általuk létrehozott negatív e-WOM a fogyasztói döntéshozatal összes lépésében megjelenhet a probléma felmerülésétől kezdve a vásárlás utáni magatartásig.

Az e-WOM tanulmányozása szorosan összekapcsolódik a sharing economy jelenséggel, amelyre példa az Airbnb, ahol kiemelt jelentósége van az online közösségnek, melynek tagjai nemcsak erőforrás-, hanem információmegosztással is segítik egymást.

A kutatás fóbb eredményei megmutatták, hogy az e-WOM jelentősen befolyásolja a résztvevók döntéseit, akik ugyanakkor nem kizárólag a negatív információk alapján döntenek, mind a pozitív, mind a negatív értékeléseket szükségesnek tartják az objektív döntéshozatalhoz. Megállapítható azonban, hogy az általuk relevánsnak tartott negatívumok többször elbizonytalanították a résztvevóket egy adott szálláshely kiválasztásától. Másrészről viszont a negatív e-WOMnak köszönhetóen az alanyok jobban fel tudnak készülni a hiányosságokra, és kijelenthető, hogy a negatív értékelések segítségével magabiztosabbá váltak a vásárlási döntésükben.

A negatív vélemények hasznosnak bizonyultak, mert felhívják a figyelmet a szállás hiányosságaira, amikkel az utazó előre számolhat. Ha a negatívumok újra és újra felmerülnek, akkor valósnak érzékelték őket megkérdezettjeink. Amennyiben a negatívum kritériumfeltétel az olvasónak, elfordul a szállástól. Viszont a szélsőségesen negatív kommenteket nem érezték életszerúnek a résztvevők, ezért azok nem is befolyásolták a döntésüket.

A kutatási eredmények alátámasztják a szakirodalmi megállapításokat, valamint felhívják a figyelmet arra, hogy a negatív véleményeknek kiemelkedó szerepe van a sharing economy jelenségében is, így nagyobb figyelmet kell szentelni ezen területek összekapcsolásának.

A kutatás korlátai között mindenképpen meg kell említenünk a kis elemszámú, nem reprezentatív mintát. Jelen tanulmányban csupán a kutatási folyamat első szakaszának eredményei kerültek bemutatásra.

\section{Felhasznált irodalom}

BAUER A. - BERÁCS J. - KENESEI ZS. (2007): Marketing alapismeretek. Aula Kiadó, Budapest.

BOROS L. - DUDÁS G. (2017): A közösségi szállásadás konfliktusai és dilemmái. Földrajzi Közlemények. 141(3). pp. 288-298.

BRIDGES, J. - VÁSQUEZ, C. (2018): If nearly all Airbnb reviews are positive, does that make them meaningless? Current Issues in Tourism. 21(18). pp. 2057-2075. 
BRONNER, F. - DE HOOG, R. (2011): Vacationers and eWOM: Who Posts, and Why, Where, and What? Journal of Travel Research. 50(1). pp. 15-26.

CHANG, H. H. - WU, H. L. (2014): An examination of negative e-WOM adoption: Brand commitment as a moderator. Decision Support Systems. 59. pp. 206-218.

CHEN, Z. - LURIE, H. N. (2013): Temporal Contiguity and Negativity Bias in the Impact of Online Word of Mouth. Journal of Marketing Research. 50(4). pp. 463-476.

CHENG, M. (2016): Sharing economy: a review and agenda for future research. International Journal of Hospitality Management. 57. pp. 60-70.

CHEUNG, C. M. - THADANI, D. R. (2012): The impact of electronic word-of-mouth communication: A literature analysis and integrative model. Decision Support Systems. 54(1). pp. 461-470.

CODAGNONE, C. - ABADIE, F. - BIAGI, F. (2016): The Passions and the Interests: Unpacking the 'Sharing Economy'. Digital Economy Working Paper. 1. Institute for Prospective Technological Studies.

CSORDÁS T. (2015): A fogyasztói részvétel mint marketingkommunikációs eszköz a digitális médiában. Doktori $(\mathrm{PhD})$ értekezés. Budapesti Corvinus Egyetem, Gazdálkodástani Doktori Iskola.

DE BRUYN, A. - LILIEN, G. L. (2008): A multistage model of word-of-mouth influence through viral marketing. International Journal of Research in Marketing. 25(3). pp. 151-163.

DUDÁS G. - BOROS L. (2019): A közösségi gazdaság (sharing economy) definiálásának dilemmái. Tér és Társadalom. 33(1). pp. 107-130.

EAST, R. - HAMMOND, K. - WRIGHT, M. (2007): The relative incidence of positive and negative word of mouth: A multi-category study. International Journal of Research in Marketing. 24(2). pp. 175-184.

ERT, E. - FLEISCHER, A. - MAGEN, N. (2016): Trust and reputation in the sharing economy: The role of personal photos in Airbnb. Tourism Management. 55. pp. 62-73.

GHEORGHE, I. R. (2018): Modeling the Online Consumer Decision-Making Process based on eWOM Communication in Health Care Services. A Romanian Perspective. Paper presented at The Annual Academy of Marketing Conference Proceedings: Marketing Dimensions, People, Places and Spaces. Bournemouth, UK.

GRUEN, T. W. - OSMONBEKOV, T. CZAPLEWSKI, A. J. (2006): eWOM: The impact of customer-to-custom-er on-line know- how exchange on customer value and loyalty. Journal of Business Research. 59(4). pp. 449-459.

GYULAVÁRI T. - MITEV A. - NEULINGER Á. - NEUMANN-BÓDI E. - SIMON J. - SZÚCS K. (2015): A marketingkutatás alapjai. Akadémiai Kiadó, Budapest.

HU, N. - PAVLOU, P. A. - ZHANG, J. (2006): Can online reviews reveal a product's true quality: Empirical findings and analytical modeling of online word-of-mouth communication. EC '06 Proceedings of the 7th ACM conference on Electronic commerce. Ann Arbor, Michigan, USA. pp. 324-330.

JANCSIK A. - MICHALKÓ G. - CSERNYIK M. (2018): Megosztás megosztottság nélkül - az Airbnb és a budapesti szálláshelypiac átalakulása. Közgazdasági Szemle. 65(3). pp. 259-286.

KENESEI ZS. - KOLOS K. (2007): Szolgáltatásmarketing és -menedzsment. Alinea Kiadó, Budapest.

KIM, E. E. K. - MATTILA, A. S. - BALOGLU, S. (2011): Effects of gender and expertise on consumers' motivation to read online hotel reviews. Cornell Hospitality Quarterly. 52(4). pp. 399-406.

LACZNIAK, N. R. - DECARLO, E. T. RAMASWAMI, N. S. (2001): Consumers' Responses to Negative Word-of-Mouth Communication: An Attribution Theory Perspective. Journal of Consumer Psychology. 11(1). pp. 57-73.

LEE, C. H. - CRANAGE, D. A. (2014): Toward understanding consumer processing of negative online word-of-mouth communication: the roles of opinion consensus and organizational response strategies. Journal of Hospitality $\mathcal{E}$ Tourism Research. 38(3). pp. 330-360.

LEE, J. - PARK, D-H. - HAN, I. (2008): The effect of negative online consumer reviews on product attitude: An information processing view. Electronic Commerce Research and Applications. 7(3). pp. 341-352.

LIANG, L. J. - CHOI, H. C. - JOPPE, M. (2018): Understanding repurchase intention of Airbnb consumers: perceived authenticity, electronic word-of-mouth, and price sensitivity. Journal of Travel \& Tourism Marketing. 35(1). pp. 73-89.

LITVIN, S. W. - GOLDSMITH, R. E. - PAN, B. (2008): Electronic word-of-mouth in hospitality and tourism management. Tourism Management. 29. pp. 458-468.

MAO, Z. - LYU, J. (2017): Why travelers use Airbnb again? An integrative approach to understanding travelers' repurchase intention. International Journal of Contemporary Hospitality Management. 29(9). pp. 2464-2482. 
MARKOS-KUJBUS É. (2016): Az online szájreklám (electronic word-of-mouth) jellemzői a marketingkommunikáció szempontjából. Vezetéstudomány. 46(6). pp. 52-63.

MARTIN-FUENTES, E. - FERNANDEZ, C. - MATEU, C. - MARINE-ROIG, E. (2018): Modelling a grading scheme for peer-to-peer accommodation: Stars for Airbnb. International Journal of Hospitality Management. 69. pp. 75-83.

ÖZ, M. (2015): Social media utilization of tourists for travel-related purposes. International Journal of Contemporary Hospitality Management. 27(5). pp. 1003-1023.

PARK, D-H. - LEE, J. (2008): eWOM overload and its effect on consumer behavioral intention depending on consumer involvement. Electronic Commerce Research and Applications. 7(4). pp. 386-398.

RESNICK, P. - ZECKHAUSER, R. (2002): Trust among strangers in Internet transactions: empirical analysis of eBay's reputation system. Advances in Applied Microeconomics. 11. pp. 127157.

RICCI, F. - WIETSMA, R. T. A. (2006): Product Reviews in Travel Decision Making. In: Hitz, M. - Sigala, M. - Murphy, J. (eds): Information and Communication Technologies in Tourism 2006. Springer, Vienna. pp. 296-307.

RIFKIN, J. (2014): The zero marginal cost society: The internet of things, the collaborative commons, and the eclipse of capitalism. St. Martin's Press, New York, NY.

SCHAEFERS, T. - LAWSON, S. J. - KUKARKINNEY, M. (2016): How the burdens of ownership promote consumer usage of accessbased services. Marketing Letters. 27(3). pp. 569577.

SCHNEIDER, B. - BOWEN, D. E. (1999): Understanding customer delight and outrage. Sloan Management Review. 41(1). pp. 35-45.
SLEE, T. (2015): What's Yours Is Mine: Against the Sharing Economy. OR Books, New York, NY.

TUSSYADIAH, I. P. - ZACH, F. (2017): Identifying salient attributes of peer-to-peer accommodation experience. Journal of Travel $\mathcal{E}$ Tourism Marketing. 34(5). pp. 636-652.

VERHAGEN, T. - NAUTA, A. - FELDBERG, F. (2013): Negative online word-of-mouth: Behavioral indicator or emotional release? Computers in Human Behavior. 29(4). pp. 14301440.

WANGENHEIM， F. V. (2005): Postswitching negative word of mouth. Journal of Service Research. 8(1). pp. 67-78.

YEN, C-L. - TANG. C-H. (2015): Hotel attribute performance, eWOM motivations, and media choice. International Journal of Hospitality Management. 46. pp. 79-88.

\section{Internetes források}

AIRBNB (2019): Fast facts. https://press.airbnb. com/fast-facts/, Letöltve: 2019. augusztus 13.

CODAGNONE, C. - MARTENS, B. (2016): Scoping the Sharing Economy: Origins, Definitions, Impact and Regulatory Issues. https://ec.europa.eu/jrc/ sites/jrcsh/files/JRC100369.pdf, Letöltve: 2019. augusztus 13.

PWC (2015): Osztogatnak vagy fosztogatnak? A sharing economy térnyerése. https:// www.pwc.com/hu/hu/kiadvanyok/assets/ pdf/sharing_economy.pdf, Letöltve: 2018. augusztus 20.

SUNDARARAJAN, A. (2014): Peer-to-peer businesses and the sharing (collaborative) economy: Overview, economic effects and regulatory issues. https://republicans-smallbusiness. house.gov/uploadedfiles/1-15-2014_revised_ sundararajan_testimony.pdf, 2019. augusztus 13. 